\title{
PENERIMAAN PASAR TERHADAP BODY BUTTER MASERAT BERAS MERAH (Oryza glaberrima Steud.)
}

\section{MARKET ACCEPTANCE OF RED RICE (Oryza glaberrima Steud.) BODY BUTTER}

\author{
NI MADE DHARMA SHANTINI SUENA*•, ALFIANA NAILI SYIRVIA*, \\ NI PUTU UDAYANA ANTARI*
}

\section{*Akademi Farmasi Saraswati Denpasar Jl. Kamboja No. 11A Denpasar, Bali}

\begin{abstract}
Abstrak: Beras berwarna mengandung lebih banyak antosianin dan antioksidan daripada beras tanpa warna (Sutharut, 2012). Beras merah sebagai salah satu jenis beras berwarna berpotensi dikembangkan menjadi produk yang mampu memberikan nilai tambah bagi produsen beras merah, maupun masyarakat pengguna produk tersebut. Untuk itu telah dilakukan formulasi body butter dari maserat beras merah. Untuk mengetahui potensi pasar produk yang dihasilkan, diperlukan penelitian untuk mengetahui penerimaan pasar terhadap body butter beras merah. Penelitian dilaksanakan dengan metode analisis deskriptif menggunakan kuesioner. Responden adalah masyarakat di Kota Denpasar yang memenuhi kriteria inklusi penelitian. Responden diminta untuk menilai kualitas body butter yang meliputi warna, aroma, kekentalan, kemudahan saat digunakan, kenyamanan saat digunakan, kemampuan melembabkan kulit, dan kemampuan meresap ke dalam kulit. Setelah dilakukan analisis data secara deskriptif diperoleh bahwa persentase penerimaan body butter maserat beras merah adalah $82.31 \%$ sehingga termasuk dalam kategori sangat diterima di pasaran.
\end{abstract}

Kata kunci: beras merah, body butter, penerimaan pasar.

Abstract: Colored rice contains more anthocyanin and antioxidants than colorless rice (Sutharut, 2012). Red rice as one type of colored rice that was developed into a product that is able to provide benefit to the producers of brown rice, as well as the people who use the product. For this reason, a body butter formulation from red rice macerate has been carried out. To find out the potential of the product produced, research is needed to find out the market for butter in brown rice. The study was carried out using descriptive analysis method using a questionnaire. Respondents were people in Denpasar City who met the research criteria. Respondents are used to assess the quality of body butter, which contains color, aroma, viscosity, current comfort, ability to moisturize the skin, and the ability to penetrate into the skin. After analyzing the data descriptively it was found that the percentage of brown rice maser butter body was $82.31 \%$ included in the very clear category on the market.

Keywords: body butter, market acceptance, red rice.

\section{PENDAHULUAN}

Hasil uji fitokimia yang telah dilakukan menunjukkan bahwa ekstrak beras merah mengandung metabolit sekunder berupa senyawasenyawa flavonoid, antosianin, tanin, terpenoid, dan kuinon. Aktivitas antioksidan ekstrak beras merah adalah sebesar 94,14\% (Dwiyanti dkk, 2013). Pada beras merah terdapat aleuron mengandung gen yang memproduksi antosianin sebagai sumber warna merah atau ungu. Pigmen antosianin ini tidak hanya pada pada perikarp dari beras saja, tetapi juga terdapat pada bagian tanaman lainnya seperti kelopak daun (Suardi, 2005). Dengan demikian beras merah berpotensi untuk dikembangkan menjadi produk antioksidan, khususnya produk kosmetik untuk perawatan kulit. Secara empiris beras sering digunakan untuk merawat kulit, namun produk kosmetik modern yang memanfaatkan beras merah belum pernah penulis temukan di pasaran.

Beras merah dapat dikembangkan menjadi produk body butter. Body butter merupakan sediaan semi padat yang memiliki proporsi minyak paling tinggi, sehingga sangat kental dan mirip margarin atau mentega. Biasanya body butter memiliki kandungan shea butter, cocoa butter, dan coconut butter. Body butter mengandung komponen minyak (cocoa butter) yang lebih tinggi sehingga memiliki kemampuan yang lebih baik

•Author Correspondence. Hp: +628563740032; e-mail: vrndaranyadasi@gmail.com 
dalam menutrisi dan menjaga kelembaban kulit daripada sediaan losion. Karena kelebihannya tersebut, body butter cocok untuk digunakan di daerah tropis dan untuk tipe kulit kering, serta bagian kulit yang tebal dan mudah pecah seperti siku, tumit, dan lutut (Suena, Antari, \& Cahyaningsih, 2017).

Uji penerimaan menyangkut penilaian seseorang akan suatu sifat atau kualitas suatu bahan sehingga dapat memberikan kesukaan pada orang. Pada uji ini responden mengemukakan tanggapan pribadi yaitu kesan yang berhubungan dengan kesukaan atau tanggapan mengenai rasa senang atau tidaknya terhadap sifat sensoris atau kualitas yang dinilai. Tujuan uji penerimaan adalah untuk mengetahui apakah suatu komoditas atau sifat sensorik tertentu dapat diterima oleh masyarakat. Uji ini tidak dapat digunakan untuk meramalkan penerimaan dalam pemasaran. Hasil uji yang meyakinkan tidak menjamin komoditas tersebut dengan sendirinya mudah dipasarkan (Susuwi, 2009).

Produk body butter yang beredar di pasaran sangat bervariatif mulai dari aroma hingga bahan aktif yang digunakan. Ruang lingkup pasar dari produk body butter ini juga sangat luas dan berpotensi terhadap pariwisata kesehatan khususnya di Bali. Berdasarkan hal tersebut, perlu dilakukan uji penerimaan pasar terhadap body butter yang berasal dari maserat beras merah agar dapat mengetahui potensi pemasaran body butter maserat beras merah.

\section{METODE PENELITIAN}

Penelitian ini merupakan penelitian deskriptif. Penelitian dilakukan pada bulan Maret-Juni 2018 dengan menggunakan kuesioner marketing research terhadap sampel yang memenuhi kriteria inklusi yaitu usia di atas 17 tahun, dapat membaca dan menulis, serta pernah menggunakan produk body butter.

Formula body butter maserat beras merah yang digunakan dalam penelitian ini tercantum dalam tabel 1. Teknik sampling yang digunakan adalah purposive sampling. Perhitungan sampel yang digunakan adalah sebagai berikut (Lemeshow, 1997).

$$
\begin{gathered}
\mathrm{n}=\frac{Z_{1-a / 2}^{2} P(1-P)}{d^{2}} \\
=\frac{(0,96)^{2} 0,5(1-0,5)}{(0,1)^{2}} \\
=96 \text { sampel }
\end{gathered}
$$

Keterangan

$$
\begin{array}{ll}
\mathrm{n} & : \text { jumlah sampel minimum } \\
Z_{1-a / 2}^{2} & : \text { derajat kepercayaan } 95 \%(1,96) \\
P & : \text { proporsi populasi } 50 \%(0,50)
\end{array}
$$

$d \quad$ : tingkat presisi atau penyimpangan terhadap populasi $(0,10)$

Jumlah sampel minimum yang diperoleh adalah 96 sampel, penelitian ini menggunakan 100 sampel.

Tabel 1. Formula Body Butter Maserat Beras

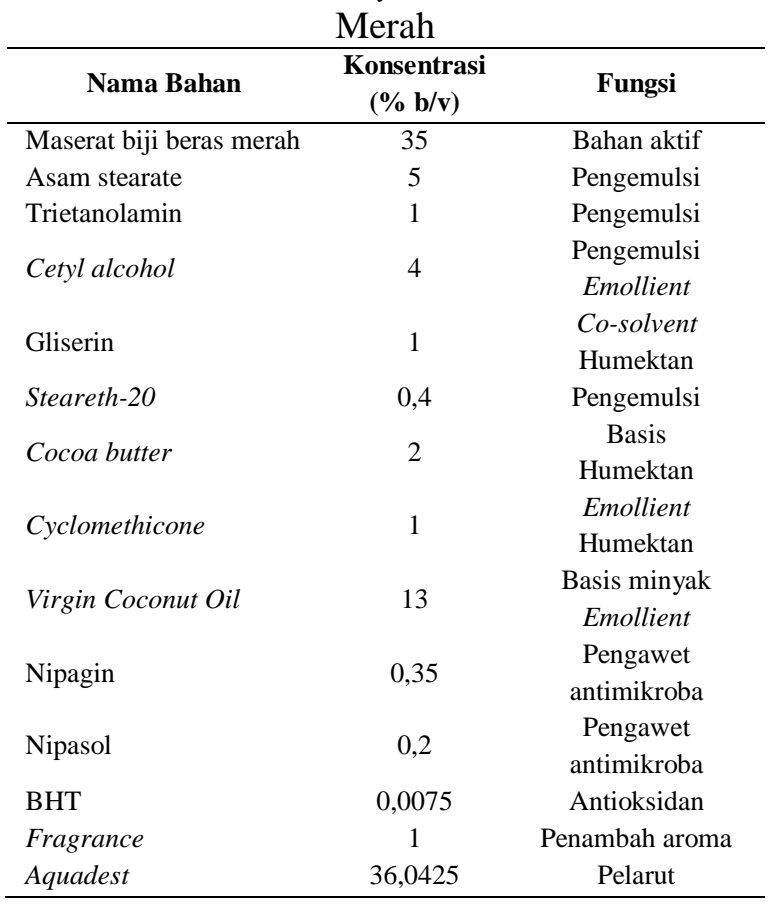

Analisis data yang digunakan adalah sebagai berikut.

1. Menentukan kategori penerimaan konsumen terhadap penilaian masing-masing faktor kualitas body butter. Skala penilaian kualitas body butter diberikan nilai masing-masing 1 sampai 5 dari kualitas sangat tidak baik sampai sangat baik. Penilaian tersebut diklasifikasikan menjadi 5 kategori penerimaan yang terdapat pada tabel 2 .

2. Persentase penilaian tiap faktor kualitas body butter diperoleh dari rata-rata penilaian dibagi skor penilaian tertinggi yaitu 5 dikalikan $100 \%$. Penilaian tersebut dijabarkan sebagai berikut.

Persentase penilaian $(\%)=\frac{\text { rata-rata penilaian }}{\text { penilaian tertinggi (5) }} \times 100 \%$ Tabel 2. Kategori Penerimaan Pasar terhadap Penilaian Responden

\begin{tabular}{cc}
\hline $\begin{array}{c}\text { Rentang } \\
\text { penilaian }(\%)\end{array}$ & Kategori \\
\hline $0-20$ & Sangat kurang diterima \\
$21-40$ & Kurang diterima \\
$41-60$ & Cukup diterima \\
$61-80$ & Diterima \\
$81-100$ & Sangat diterima \\
\hline
\end{tabular}


3. Menentukan kategori penerimaan terhadap penilaian total dari seluruh faktor kualitas body butter.

4. Menentukan penilaian terhadap faktor-faktor yang perlu diperbaiki dari body butter maserat beras merah. Untuk menilai faktor-faktor tersebut termasuk perlu diperbaiki atau tidak, maka dikelompokkan dalam kategori sesuai tabel 3 .

Tabel 3. Kategori Perbaikan Faktor Kualitas Body Butter

\begin{tabular}{cc}
\hline Rentang Penilaian (\%) & Kategori \\
\hline $51-100$ & Perlu diperbaiki \\
$1-50$ & Tidak perlu diperbaiki
\end{tabular}

5. Mengelompokkan ranking dari faktor-faktor kualitas yang dipertimbangkan konsumen dalam pemilihan body butter. Ranking penilaian responden dijabarkan dalam persamaan sebagai berikut.

Ranking penilaian responden $=(n \times 1)+\cdots+(n \times 7)$

Keterangan:

$n=$ jumlah responden yang memberikan ranking

1 sampai 7 = ranking

ranking penilaian responden dihitung tiap faktor kualitas body butter

\section{HASIL}

Karakteristik responden, penerimaan body butter maserat beras merah, dan penilaian pasar terhadap pemilihan body butter.

Sebaran karakteristik responden menunjukkan jenis kelamin responden terbanyak adalah perempuan yaitu sebesar $79 \%$. Sedangkan latar belakang pendidikan responden terbanyak adalah lulusan sekolah menengah atas yaitu sebesar $78 \%$. Karakteristik usia responden terbanyak adalah responden berusia 21 - 30 tahun yaitu sebesar 50\% responden.

Penilaian kualitas body butter disajikan pada tabel 4. Aroma body butter, kekentalan body butter, kemudahan body butter saat digunakan, kenyamanan body butter saat digunakan, serta kemampuan body butter dalam melembabkan kulit termasuk kategori sangat diterima oleh pasaran. Sedangkan warna body butter dan kemampuan body butter meresap dalam kulit menunjukkan tingkatan yang lebih rendah yaitu diterima konsumen.
Tabel 4. Hasil Penilaian dan Kategori Penerimaan Kualitas Body Butter Maserat Beras

\begin{tabular}{|c|c|c|}
\hline \multicolumn{3}{|c|}{ Merah } \\
\hline Faktor & $\begin{array}{l}\text { Nilai } \\
(\%)\end{array}$ & Kategori \\
\hline Warna body butter & 78.00 & diterima \\
\hline Aroma body butter & 81.60 & $\begin{array}{c}\text { sangat } \\
\text { diterima }\end{array}$ \\
\hline $\begin{array}{l}\text { Kekentalan body } \\
\text { butter }\end{array}$ & 85.80 & $\begin{array}{c}\text { sangat } \\
\text { diterima }\end{array}$ \\
\hline $\begin{array}{l}\text { Kemudahan saat } \\
\text { digunakan }\end{array}$ & 84.60 & $\begin{array}{c}\text { sangat } \\
\text { diterima }\end{array}$ \\
\hline $\begin{array}{l}\text { Kenyamanan saat } \\
\text { digunakan }\end{array}$ & 84.00 & $\begin{array}{c}\text { sangat } \\
\text { diterima }\end{array}$ \\
\hline $\begin{array}{l}\text { Kemampuan } \\
\text { melembabkan kulit }\end{array}$ & 82.60 & $\begin{array}{c}\text { sangat } \\
\text { diterima }\end{array}$ \\
\hline $\begin{array}{l}\text { Kemampuan meresap } \\
\text { dalam kulit }\end{array}$ & 79.60 & diterima \\
\hline Total rata-rata & 82.31 & $\begin{array}{c}\text { Sangat } \\
\text { diterima }\end{array}$ \\
\hline
\end{tabular}

Secara keseluruhan diperoleh persentase nilai kualitas body butter beras merah adalah $82.31 \%$. Persentase nilai tersebut berada diantara $81 \%$ $100 \%$ sehingga dari keseluruh faktor tersebut, body butter maserat beras merah dikategorikan sangat diterima di pasaran.

Selain penilaian kualitas body butter maserat beras merah, responden juga diminta untuk memberi masukan faktor-faktor yang masih perlu diperbaiki dari sediaan body butter maserat beras merah yang dihasilkan. Hasil penilaian responden terhadap faktor yang perlu diperbaiki pada body butter maserat beras merah terdapat pada tabel 5 .

Tabel 5. Penilaian Responden Terhadap

Faktor yang Perlu Diperbaiki dari Body Butter Maserat Beras Merah

\begin{tabular}{|c|c|c|}
\hline Faktor Perbaikan & Penilaian & Kategori \\
\hline Warna body butter & $59 \%$ & Perlu diperbaiki \\
\hline Aroma body butter & $51 \%$ & Perlu diperbaiki \\
\hline $\begin{array}{l}\text { Kekentalan body } \\
\text { butter }\end{array}$ & $25 \%$ & $\begin{array}{c}\text { Tidak perlu } \\
\text { diperbaiki }\end{array}$ \\
\hline $\begin{array}{l}\text { Kemudahan saat } \\
\text { digunakan }\end{array}$ & $26 \%$ & $\begin{array}{c}\text { Tidak perlu } \\
\text { diperbaiki }\end{array}$ \\
\hline $\begin{array}{l}\text { Kenyamanan saat } \\
\text { digunakan }\end{array}$ & $24 \%$ & $\begin{array}{c}\text { Tidak perlu } \\
\text { diperbaiki }\end{array}$ \\
\hline $\begin{array}{l}\text { Kemampuan } \\
\text { melembabkan kulit }\end{array}$ & $33 \%$ & $\begin{array}{l}\text { Tidak perlu } \\
\text { diperbaiki }\end{array}$ \\
\hline $\begin{array}{l}\text { Kemampuan } \\
\text { meresap dalam kulit }\end{array}$ & $38 \%$ & $\begin{array}{c}\text { Tidak perlu } \\
\text { diperbaiki }\end{array}$ \\
\hline
\end{tabular}

Responden juga diminta untuk mengurutkan faktor-faktor kualitas yang dipertimbangkan dalam memilih body butter di pasaran. Informasi yang diperoleh dapat digunakan sebagai masukan dalam mengembangkan body butter beras merah maupun 
pengembangan formula body butter lainnya. Ranking faktor-faktor kualitas yang dipertimbangkan dalam pemilihan body butter di Pasaran disajikan dalam tabel 6.

Tabel 6. Ranking Faktor-Faktor Kualitas yang Dipertimbangkan dalam Pemilihan Body Butter di Pasaran

\begin{tabular}{ccc}
\hline Ranking & Faktor & $\begin{array}{c}\text { Penilaian } \\
\text { Responden }\end{array}$ \\
\hline 1 & B & 284 \\
2 & E & 355 \\
3 & D atau F & 377 \\
4 & D atau F & 377 \\
5 & A & 414 \\
6 & G & 470 \\
7 & C & 503 \\
\hline
\end{tabular}

Keterangan:
A : warna body butter
B : aroma body butter
C : kekentalan body butter
D : kemudahan saat digunakan
E : kenyamanan saat digunakan
F : kemampuan melembapkan kulit
G : kemampuan meresap di kulit

Hasil penilaian pasar terhadap pemilihan body butter di pasaran diperoleh berdasarkan urutan ranking dari faktor-faktor kualitas body butter yang dinilai konsumen.

\section{PEMBAHASAN}

Menurut Susuwi (2009), uji penerimaan menyangkut penilaian seseorang akan suatu sifat atau kualitas suatu bahan sehingga dapat memberikan kesukaan pada orang. Terdapat tujuh faktor yang dinilai pada hasil penerimaan body butter maserat beras merah, yaitu warna body butter, aroma body butter, kekentalan body butter, kemudahan saat digunakan, kenyamanan saat digunakan, kemampuan melembabkan kulit, dan kemampuan meresap dalam kulit. Secara keseluruhan diperoleh hasil dengan kategori sangat diterima di pasaran yaitu $82.31 \%$.

Setelah penilaian faktor terhadap kualitas body butter, responden diminta untuk mengurutkan dengan ranking dari faktor yang paling pertama dipertimbangkan dalam pemilihan body butter di pasaran. Pengurutan ranking ini dilakukan untuk mengetahui faktor yang dipentingkan dalam memilih body butter di pasaran. Berdasarkan pengurutan ranking tersebut, masyarakat lebih mementingkan aroma body butter sebagai ranking pertama kemudian kenyamanan saat digunakan, kemudahan saat digunakan dan kemampuan melembabkan kulit, warna body butter, kemampuan meresap dalam kulit, dan yang terakhir adalah kekentalan body butter. Sehingga hal ini dapat berpengaruh terhadap pertimbangan dalam melakukan perbaikan kualitas body butter yang dibuat.

Penilaian responden terhadap faktor yang perlu diperbaiki adalah warna body butter dan aroma body butter. Dimana 59\% responden yang menyatakan warna body butter perlu diperbaiki dan 51\% menyatakan aroma body butter perlu diperbaiki. Pemilihan faktor warna body butter ini dapat dikarenakan warna sediaan yang kurang menarik dan sedikit pucat, kemudian dalam pemilihan aroma body butter sebagai faktor selanjutnya yang perlu diperbaiki dapat dikarenakan penambahan aroma yang kurang atau persepsi konsumen terhadap kesukaan aroma tertentu.

Uji penerimaan pasar ini dilakukan untuk mengetahui seberapa diterima produk body butter maserat beras merah di pasaran. Hasil pengujian yang menyatakan sangat diterimanya body butter maserat beras merah berarti sudah benar-benar diterima di pasaran tetapi belum tentu dapat menjamin komoditas tersebut mudah dipasarkan (Susuwi, 2009).

\section{SIMPULAN}

Body butter maserat beras merah diterima di pasaran dengan persentase penerimaan sebesar $82.31 \%$ dan berdasarkan kategori penerimaan pasar termasuk sangat diterima di pasaran. Hasil yang menunjukkan diterimanya body butter maserat beras merah hanya digunakan sebagai dasar bahwa produk tersebut dapat diterima di pasaran.

\section{UCAPAN TERIMA KASIH}

Ucapan terima kasih diberikan semua pihak yang membantu dalam penyelesaian jurnal ini terutama kepada responden yang bersedia mengisi kuesioner marketing research dalam penelitian ini.

\section{DAFTAR PUSTAKA}

Ansel, H.C, 1989, Pengantar Bentuk Sediaan Farmasi, diterjemahkan oleh Farida Ibrahim, Asmanizar, Iis Aisyah, Edisi keempat, UI Press, Jakarta. 
Dwiyanti, Gebi, Wiwi Siswaningsih dan Wulan Nur Aprilianti, 2013, 'Aktivitas Antioksidan Ekstrak Beras Merah dan Beras Hitam Komersial serta Produk Olahannya'. Seminar Nasional kimia dan Pendidikan Kimia V, Kontribusi Kimia dan Pendidikan Kimia dalam Pembangunan Bangsa yang Berkarakter, Universitas Sebelas Maret, Surakarta, hal 626-630.

Lemeshow, 1997, Besar Sampel Dalam Penelitian Kesehatan, Gadjah Mada University Press, Yogyakarta.

Suardi K., Didi, 2005, Potensi Beras Merah Untuk Peingkatan Mutu Pangan, Jurnal Litbang Pertanian Bogor, 24(3):93-100

Suena, N. M. D. S., Antari, N. P. U., \& Cahyaningsih, E. (2017). Physical Quality
Evaluation Of Body Butter Formulation From Etanol Extract Of Mangosteen (Garcinia Mangostana L.) Rind. Jurnal Ilmu Kefarmasian Indonesia, 15(1), 63-69. Retrieved from http://jifi.farmasi.univpancasila.ac.id/index.p hp/jifi/article/view/455/303

Susuwi, S, 2009, Penilaian Organoleptik, Universitas Pendidikan Indonesia, Bandung.

Sutharut, J., \& Sudarat, J. (2012). Total anthocyanin content and antioxidant activity of germinated colored rice. International Food Research Journal, 19(1).

Voigt, R., 1984, Buku Pelajaran Teknologi Farmasi, Diterjemahkan Oleh Soewandhi, S.N., Edisi V, Gadjah Mada University Press, Yogyakarta. 